Editorial

\title{
Editorial: New Perspectives on Food Democracy
}

\author{
Basil Bornemann ${ }^{1, *}$ and Sabine Weiland ${ }^{2}$ \\ ${ }^{1}$ Sustainability Research Group, Department of Social Sciences, University of Basel, 4051 Basel, Switzerland; \\ E-Mail: basil.bornemann@unibas.ch \\ 2 European School of Political and Social Sciences, Université Catholique de Lille, 59016 Lille Cedex, France; \\ E-Mail: sabine.weiland@univ-catholille.fr \\ * Corresponding author
}

Submitted: 21 October 2019 | Published: 28 October 2019

\begin{abstract}
With the overall intention of stimulating the debate on food democracy, this thematic issue aims to shed fresh light on the complex relationship between food and democracy in different contexts. New theoretical perspectives and empirical analyses are presented that explore, sharpen, question, and expand the potential of food democracy as both, an analytical lens onto the state and development of contemporary food systems, and as a political idea for transforming the dominant agri-industrial food system. In this editorial to the thematic issue "New Perspectives on Food Democracy," we briefly recapitulate the existing debate on food democracy, explain the goals and overarching questions of the thematic issue and provide an overview of the assembled articles.
\end{abstract}

\section{Keywords}

democratic governance; food citizenship; food democracy; food system; participation

\section{Issue}

This editorial is part of the issue "New Perspectives on Food Democracy" edited by Basil Bornemann (University of Basel, Switzerland) and Sabine Weiland (Université Catholique de Lille, France).

(C) 2019 by the authors; licensee Cogitatio (Lisbon, Portugal). This article is licensed under a Creative Commons Attribution 4.0 International License (CC BY).

\section{Food Democracy Debate}

The globalised food system of the 21st century is characterised by unprecedented productivity, which some see as a central factor for achieving food security and fighting world hunger. Others, however, highlight considerable negative social and ecological consequences. Current patterns of food production, distribution, and consumption are regarded as not only unjust but destructive to natural resources and livelihoods. Existing exploitative economic relations contribute to food insecurity and malnutrition for millions of people, livelihood crises, environmental destruction resulting from resource and fossil-fuel intensive production and distribution, as well as the degenerative diseases associated with the Western lifestyle's diet being rich in fat, sugar, and processed foods. These critical perspectives on the current food system are articulated in various alternative visions of the food system.
Ideas and concepts such as 'food sovereignty,' 'food justice,' 'food citizenship,' and 'food democracy' (Booth \& Coveney, 2015; Holt-Gimenez \& Shattuck, 2011; Levkoe, 2006; Renting, Schermer, \& Rossi, 2012) emerged at the intersection of critical agri-food movements such as 'La Via Campesina' and a critically-oriented academic community (Constance, Renard, \& Rivera-Ferre, 2014; Goodman, DuPuis, \& Goodman, 2012). These concepts are closely related, as they all denote a strong move to problematise the existing industrial agri-food system and present counter-proposals to remedy the current system's problems. Yet, due to the particular contexts in which they emerged, there are differences between these concepts in terms of the elements of the current food system they problematise as well as the goals, norms, and transformation strategies they promote.

The concept of food democracy, which is at the centre of this thematic issue, deals with the problematisation and transformation of established structures, pro- 
cesses, and practices of food governance, i.e., the way in which common and collectively binding goals are formed, agreed upon, and implemented. From a food democracy perspective, the rebuilding of the food system fundamentally depends on the adoption of democratic principles and practices in food governance. Instead of profitoriented multinational corporations as well as international networks of scientific and administrative experts who are making critical decisions regarding the food system without a clear democratic mandate, it is the citizens affected by food issues who are supposed to shape food systems in line with their ideas and interests in a democratically organised process of will formation and decision-making.

\subsection{Origin and Concept}

The term 'food democracy' was prominently coined in the late 1990s by Tim Lang (1999), a London City University professor and former farmer. Lang himself dates the beginnings of food democracy back to 19th century industrialisation when in England and other countries demands for adequate, affordable, and safe food were made as part of early welfare policies (Lang, 1999, p. 218). Nowadays, the term essentially refers to a counter-concept to the dominant food governance regime, which according to Lang can be described in different practices of 'food control'. Firstly, food control takes the form of centralisation and concentration processes in the food industry with some major global companies dominating the food markets at the expense of smaller firms and small farmers (Lang, 1999). Secondly, the companies exert control over food vis-à-vis the consumers. In current food supply chains, retailers, and supermarkets 'choice-edit' the products before they are presented to the consumers. Retailers act as the main gatekeepers between producers and consumers, e.g., through contracts and specifications that frame farmers' and producers' opportunities as well as consumer choice (Lang, 2005). Food labelling is also a tool for consumer control. In a context of often low-profile legal requirements for food labelling, companies only reveal information regarding the origin, production processes, and ingredients which will not negatively affect their sales (Hamilton, 2005). By restricting information and choice through their limiting of the consumers' right to know what is in their food, these corporations, thirdly, also control public, democratic decision-making. Regarding genetically modified foods, Shiva (2014) argues that corporate control of technology and intellectual property enables corporate decision-making outside of the democratic realm, which she dubs 'food dictatorship.'

Food democracy, in contrast, calls for people to regain control over the food system. The aim is to challenge and counterbalance food control choices and choiceedit of the food industry, in order to allow people access to an adequate, safe, nutritious, sustainable food supply and to collectively benefit from the food system
(Booth \& Coveney, 2015; Lang, 1999). This is achieved through greater participation of citizens and by increasing public standards in democratically accountable ways (Hassanein, 2003; Lang, 2005). The contested debates on food are thus "representing a struggle between those economic and social forces seeking to control the system and those citizens seeking to create more sustainable and democratic food systems" (Hassanein, 2008, p. 287). Food democracy serves to counterbalance the neoliberal agenda of a globalised food industry directed at feeding the world cheaply and profitably (Goodman et al., 2012; Lang \& Heasman, 2004). It is about establishing justice and fairness in the system. It creates spaces for the individual and collective agency of people to determine the values they want in their food system. The multiplicity of inputs and initiatives at various levels is seen as an asset since it can bring about innovations that will progressively transform the system. Surely, this presents a challenge to the established food system and its key players who seek to control the system, as well as a challenge to liberal democracies and market economies (Hassanein, 2003; Renting et al., 2012). Food democracy is not only seen as functional in terms of its ability to provide solutions to the problems of the current food system. A strong food democracy constitutes in itself a space for developing possibilities for "a genuine transformation of societal values and practices" (Hassanein, 2003, p. 85; see also Barber, 2004).

Food democracy comes with great hope that the democratic process will be able to bring about such change. At its core is the idea that all people meaningfully participate in shaping food systems locally, nationally, and globally. They realise that food is political (Hassanein, 2003). As set out in manifestos of the food movement, such as Frances Moore Lappé's Diet for a Small Planet (1971) and Michael Pollan's In Defense of Food (2008), people realise that, by eating differently, they can transform the agri-food system into a more just and sustainable place. The notion of 'food citizenship' denotes the altered role of people in this scenario: Rather than passive consumers, manipulated by supermarkets and deskilled through the proliferation of convenience foods, people become food citizens who get engaged and actively shape the food system (Welsh \& MacRae, 1998; Wilkins, 2005). Citizenship implies that the commodification of food is contested and that people hold and develop capacities and responsibilities beyond the simple consumption of goods. Making food choices often involves decisions in the face of conflicting values and uncertainty over wider impacts. These decisions must "be determined socially and politically through meaningful civic participation and political engagement by an informed citizenry" (Hassanein, 2008, p. 289). Some decisions might be difficult to make, but people will eventually agree with an outcome if it resulted from a fair and participatory process. Empowering people to meaningfully participate and to determine food policies and practices is a key element. In that respect, food democracy 
is also concerned with the problematisation and transformation of established views and practices of democratic governance per se. The rebuilding of the food system is frequently seen as a stimulus to explore new ways of democratic decision-making and an opportunity to reassert the institutions of liberal representative democracy, as well as to reject elitist forms of governance altogether.

\subsection{Food Democracy in Practice}

In practice, the ways of producing food democracy are manifold. It begins on the individual or family level in people's households and kitchens. People may practise food democracy for example by home cooking and cooking from scratch, using little or no prepared foods from the supermarket. This is not only an act of improving cooking skills which, as evidence shows, is related to enhanced diet quality (Larson, Perry, Story, \& Neumark-Sztainer, 2006). It is also an act of self-empowerment to regain control over food. People may also decide to consume foods that represent certain values, such as organic, local, cruelty-free, Fair Trade, etc. Being intentional about daily food choices creates added value on a personal level, but also sends signals to the marketplace and supports the producers of such foods (Booth \& Coveney, 2015; Wilkins, 2005).

Food democracy can also be practised at the community level. People may get involved in food swaps with neighbours, buy at farmers' markets, participate in consumer-supported agriculture (e.g., green box schemes), be active in a community garden project, a consumer food co-op, and so on (Booth \& Coveney, 2015). These acts go beyond the individual and household level and refer to varying degrees to the larger food system. Finally, food democracy at the societal (regional or national) level includes food advocacy and lobbying for the 'common good,' getting involved in a food movement (e.g., 'Slow Food' or the German 'Wir haben es satt' - 'we are fed up'-movement), a food policy council, and other means of civic participation in public policymaking (Goodman et al., 2012; Welsh \& MacRae, 1998).

All of these are spaces to practise food democracy by bringing control of the food system back into the hands of the people. This is seen as an act of transforming passive consumers into active food citizens. Hassanein (2008) made a first and widely cited attempt to operationalise the key dimensions required for such empowerment of people. She proposes the following five dimensions, namely: 1) Collaborating toward food system sustainability, indicating that food democracy requires not only individual participation of people in various places but also their collaboration; 2) Becoming knowledgeable about food and the food system, which is an act of countering corporate control of food; 3) Sharing ideas about the food system with others, pointing to the deliberation of values and visions about the food systems people would like to have; 4) Developing efficacy with respect to food and the food system, referring to people's capacity to be able to promote change of the food system; and 5) acquiring an orientation towards the community good, which involves people's food relations moving beyond their individual self-interest to being oriented towards the common good. These dimensions represent normative characteristics of food democracy but can also serve as criteria to empirically analyse the various food initiatives that are presently emerging (Hassanein, 2008).

\subsection{Boundaries}

The concept of food democracy, as outlined, revolves around the notions of food citizenship, participation, taking back control, and strong democracy. Essentially, food democracy is a normative counter-concept to the current food system dominated by corporate interests. Deviating from this understanding, a number of voices propose more liberal interpretations of food democracy. These are based on accounts of political consumerism, i.e., purchasing food products for ethical or political reasons (Micheletti \& Boström, 2013), and consumer rights to an informed food choice (Campisi, 2016; de Tavernier, 2012). The food citizen is constructed here as the consumer who 'votes with their fork,' and as a bearer of legal rights, e.g., regarding their right to safe food and food information. In a liberal conception, the latter is not a positive right in the sense of entitlement but rather a negative right not to be misinformed regarding their food choices. Appropriate food labelling is therefore crucial. According to some scholars, this should also contain information on ethical and environmental aspects of food products and production processes (Beekman, 2008; Micheletti \& Boström, 2013).

The main difference between these contrasting interpretations of food democracy lies in the conception of food citizenship: Whereas liberal concepts see people as 'consumer-citizens' who use their buying power in order to bring about change in the food system, the proponents of a more substantive notion of food citizenship are critical of the, in their view, passive role of the food consumer. They advocate instead a more active and political engagement in collective food affairs. From this perspective, food democracy goes beyond simply the adequate supply of food for individuals and stresses the importance of the wider public good, i.e., human and ecological health, as well as social justice (Booth \& Convey, 2015; Hassanein, 2003).

\section{New Perspectives on Food Democracy}

This thematic issue aims to conceptually and empirically advance the discussion on food democracy. The consideration of new perspectives is motivated by two contrasting, yet linked observations. The first relates to the existing discourse on food democracy, which seems to have undergone a certain stabilisation and closure. Food democracy has become an important and recurring refer- 
ence point for scholars and practitioners. In conceptual terms, however, the debate mainly revolves around a specific notion of empowerment and increased participation of people, or the contrasting notion of liberal marketbased and consumerist food democracy. Other forms of organising and doing democracy tend to be neglected.

The second observation is related to developments surrounding the food democracy debate that renew the relevance of food democracy, and at the same time change the conditions of its meaning. On one hand, the food system is marked by various developments that come with new opportunities and challenges to its democratic governance. In the last years, we observe a significant and increasing politicisation of food, triggered by food crises and scandals, concerns such as sustainability and climate change, but also by a more general politicisation of everyday life (Herring, 2015; Micheletti \& Stolle, 2012). On the other hand, the understanding and practice of democratic governance have undergone a major transformation, with potential implications for the notion of food democracy. Recent upheavals of populist movements aside (which certainly change the political conditions of democratic food governance), there are other more systemic transformations in contemporary democracies evolving, some of which may serve as explanatory factors for populist movements. In the context of recent pluralisation and decentralisation, the concepts and institutions of liberal democratic governance are said to be fundamentally transformed, if not hollowed out as suggested by some observers (Crouch, 2010). Democracy is increasingly becoming a practice to be thought of and analysed in relation to a highly complex (post-liberal) governance system, transcending the notion of a neatly organised structure of functionally linked institutions and practices satisfying the principles of a liberal representative democracy (Bevir, 2014; Peters \& Tatham, 2016; Rosanvallon, 2011; Sørensen \& Torfing, 2005). This democratic transformation comes with new challenges and opportunities for food democracy-and thus calls for a reconsideration of the conceptual repertoire for analysing food democracy.

Taking these developments into account, the concept of food democracy may open up new perspectives to illuminate the interplay between changes in the food system and transformations of democratic governance. It allows new insights into the democratic conditions and consequences of recent developments in the food system. Conversely, it can shed new light on the consequences of recent democratic transformations for the governance of contemporary food systems. With the general intention to gain fresh theoretical and empirical insight into the complex and dynamically changing relationship between food and democracy in different contexts, as well as to examine the theoretical and practical significance of food democracy today, the thematic issue pursues three objectives, each related to a specific set of questions:
1. The first aim is to deepen, differentiate and further develop the conceptual repertoire for the analysis of food democracy: What are the established approaches and how can food democracy be understood today? To what extent have existing understandings proved useful and how do they need to be adapted in the light of recent developments in food systems and democracy? What are appropriate concepts for a differentiated analysis of the democratic quality of contemporary food governance or the food system as a whole?

2. The second aim is to generate new empirical insights about (old and new) phenomena of food democracy: How are food concerns being articulated, processed, and regulated in modern democracies? Which forms of food democracy can we observe? How significant and/or prevalent is democracy in the food system? Do we find indications of a democratisation of food? Are there counter-movements? What are drivers of and barriers to the democratisation of food?

3. The third aim is practical-political. It refers to the identification of approaches and strategies for promoting different forms of food democracy. How can food systems be democratised? What strategies and practices strengthen democracy in relation to food?

\section{Mapping the Contributions to the Thematic Issue}

The contributions assembled in this thematic issue examine a wide array of ways in which food and democracy are connected. They are based on different normative and analytical reference points, focus on different objects or places of manifestation of food democracy, and make use of different approaches and methods.

In terms of their normative theoretical foundations, the spectrum ranges from contributions based on and developing established participatory notions of food democracy to contributions that problematise existing normative concepts and place them on new democratic foundations, as well as establishing links to other normative concepts such as sustainability and justice. Also, from an analytical point of view, a wide range of references to concepts such as governance, power, conflict, and transformation can be identified. Here, too, some contributions take new paths, for example by emphasising the sensual dimension of food democracy or by anchoring food democracy in the practice of knowledge.

There is also a considerable variation in the subject areas covered. The contributions focus on various manifestations of food democracy, ranging from bottomup initiatives and networks to top-down governance. Some contributions are particularly interested in how social and government initiatives work together to create food democracy. Within these different places, the contributions focus on different 'aggregate states' of food democracy-from institutional arrangements to dis- 
courses, and cognitive structures to concrete practices. Irrespective of this variation in relation to the objects, a certain dominance of contexts can be discerned. The majority of contributions to food democracy focus on Western countries, while the countries of the Global South rarely appear. In this broader cultural context, a focus on urban settings prevails. It is possible that this focus is not random, but reflects a systematic affinity between food democracy and Western contexts (see Carlson \& Chappell, 2015).

The methodological spectrum includes theoretically accentuated as well as empirically oriented contributions. The latter range from analyses of new primary data to reinterpretations of existing studies from the perspective of food democracy. They include in-depth qualitative case studies as well as approaches to comparing manifestations of food democracy on the basis of quantitative data. While these approaches reflect the classical spectrum of social science methods, transformative research approaches such as participatory action research or participatory experiments express the hybrid character of food democracy as both an analytical and a practical concept.

Notwithstanding these differences, the contributions to the thematic issue share the common goal of taking on and developing new perspectives on food democracy. To highlight their respective novelty, we have grouped the articles into three sections that highlight three different innovation movements we observe in relation to the existing debate on food democracy.

A first group of contributions, entitled 'elaborating and differentiating food democracy,' ties in with existing concepts of food democracy, deepening, detailing, and differentiating them on the basis of empirical analyses. Here we find studies on the democratic qualities of foodsharing initiatives (Davies, Cretella, \& Franck, 2019) and alternative food networks (Lohest, Bauler, Sureau, Van Mol, \& Acten, 2019), both in urban governance contexts. Two articles analyse the democratic potential of food policy councils in different contexts and reflect the empirical lessons for the concept of food democracy (Bassarab, Clark, Santo, \& Palmer, 2019; Sieveking, 2019). Two further contributions focus on the special role of state actors in shaping food-related participation (Baldy \& Kruse, 2019; van de Griend, Duncan, \& Wiskerke, 2019). The part concludes with two articles on the democratic implications of governance innovation, either bottom-up as produced in local food initiatives (Fernandez-Wulff, 2019) or top-down as anchored in new ideas of behavioural governance (Gumbert, 2019).

A second group of articles is concerned with 'exploring and pushing food democracy' in conceptual and empirical terms. It contains contributions that clarify, reflect, and extend the theoretical foundations of food democracy beyond the usual participatory or liberal perspectives: by comprehending the empowerment claims of food democracy in the sense of a powerbased concept of complex democracy (Bornemann \&
Weiland, 2019); by proposing the tying of food democracy back to different dimensions of democratic legitimacy (Behringer \& Feindt, 2019); or by distinguishing different conceptions and arenas of democratic participation (Lorenzini, 2019). Other articles advance the notion of food democracy by applying it to new thematic areas, such as the context of economic deprivation (Prost, 2019) or the historical design of urban food policy (Hasson, 2019). Broadening this perspective on the production of food democracy, two further articles examine the role of technological conflict in the creation of food democracy (Friedrich, Hackfort, Boyer, \& Gottschlich, 2019) and the role of land investment in Africa in the rise and fall of the democratic quality of African food systems (Dekeyser, 2019).

A third group of contributions can be characterised as 'challenging and enlarging food democracy.' Rather than refining or pushing existing concepts, they propose more radical reconsiderations and extensions of the current understanding of the concept. This includes critical readings of food democracy from a governmentality (Jhagroe, 2019) or a neo-Marxist perspective (Tilzey, 2019). Other contributions reach for new terrain of the concept, when working out the epistemic foundations of food democracy (Adelle, 2019), or the democratic implications of taste and sensory experience as a part of food democracy (Voß \& Guggenheim, 2019).

While all contributions provide new insights into food democracy, many articles identify additional topics for future research and practice. We hope that this rich pool of novel perspectives will provide an inspiring basis for exploring new ways of 'knowing' and 'doing' food democracy.

\section{Acknowledgments}

We would like to thank the participants of the panel "Interpreting Food Democracy" at the 12th International Conference on Interpretive Policy Analysis 2017 in Lancaster, UK, in the context of which the idea to this thematic issue was born. Special thanks go to Esther Seha, who was involved in early discussions on the subject. We would also like to extend our gratitude to the many reviewers for their constructive feedback, which greatly helped in improving the contributions. Finally, we also thank the editorial office of Politics and Governance for their support and patience during the production process.

\section{Conflict of Interests}

The authors declare no conflict of interests.

\section{References}

Adelle, C. (2019). The role of knowledge in food democracy. Politics and Governance, 7(4), 214-223.

Baldy, J., \& Kruse, S. (2019). Food democracy from the 
top down? State-driven participation processes for local food system transformations towards sustainability. Politics and Governance, 7(4), 68-80.

Barber, B. (2004). Strong democracy: Participatory politics for a new age. Berkeley, CA: University of California Press.

Bassarab, K., Clark, J. K., Santo, R., \& Palmer, A. (2019). Finding our way to food democracy: Lessons from US food policy council governance. Politics and Governance, 7(4), 32-47.

Beekman, V. (2008). Consumer rights to informed choice on the food market. Ethical Theory and Moral Practice, 11(1), 61-72. https://doi.org/10.1007/s10677007-9075-5

Behringer, J., \& Feindt, P. H. (2019). How shall we judge agri-food governance? Legitimacy constructions in food democracy and co-regulation discourses. Politics and Governance, 7(4), 119-130.

Bevir, M. (2014). Decentering governance: A democratic turn? In B. Isakhan \& S. Slaughter (Eds.), Democracy and crisis (pp. 25-43). London: Palgrave Macmillan. https://doi.org/10.1057/9781137326041_2

Booth, S., \& Coveney, J. (2015). Food democracy: From consumer to food citizen. London: Springer.

Bornemann, B., \& Weiland, S. (2019). Empowering people: Democratising the food system? Exploring the democratic potential of food-related empowerment forms. Politics and Governance, 7(4), 105-118.

Campisi, J. (2016). Food citizenship. In P. B. Thompson \& D. M. Kaplan (Eds.), Encyclopedia of food and agricultural ethics (1-5). Dordrecht: Springer. https://doi. org/10.1007/978-94-007-6167-4_585-1

Carlson, J., \& Chappell, M. J. (2015). Deepening food democracy: The tools to create a sustainable, food secure and food sovereign future are already hereDeep democratic approaches can show us how. Minneapolis, MN: Institute for Agriculture and Trade. Retrieved from https://www.iatp.org/sites/default/ files/2015_01_06_Agrodemocracy_JC_JC_f_0.pdf

Constance, D. H., Renard, M. C., \& Rivera-Ferre, M. G. (Eds.). (2014). Alternative agrifood movements: Patterns of convergence and divergence. Bingley: Emerald. https://doi.org/10.1108/S1057-19222014 0000021013

Crouch, C. (2010). Post-democracy. Cambridge: Polity Press.

Davies, A. R., Cretella, A., \& Franck, V. (2019). Food sharing initiatives and food democracy: Practice and policy in three European cities. Politics and Governance, $7(4), 8-20$.

de Tavernier, J. (2012). Food citizenship: Is there a duty for responsible consumption? Journal of Agricultural and Environmental Ethics, 25(6), 895-907. https:// doi.org/10.1007/s10806-011-9366-7

Dekeyser, K. (2019). Land investments, food systems change and democracy in Kenya and Mozambique. Politics and Governance, 7(4), 178-189.

Fernandez-Wulff, P. (2019). Collective agency in the mak- ing: How social innovations in the food system practice democracy beyond consumption. Politics and Governance, 7(4), 81-93.

Friedrich, B., Hackfort, S., Boyer, M., \& Gottschlich, D. (2019). Conflicts over GMOs and their contribution to food democracy. Politics and Governance, 7(4), 165-177.

Goodman, D., DuPuis, E., \& Goodman, M. (2012). Alternative food networks: Knowledge, practice and politics. Abingdon: Routledge.

Gumbert, T. (2019). Anti-democratic tenets? Behavioural-economic imaginaries of a future food system. Politics and Governance, 7(4), 94-104.

Hamilton, N. D. (2005). Food democracy II: Revolution or restoration. Journal of Food Law \& Policy, 1(1), $13-42$.

Hassanein, N. (2003). Practicing food democracy: A pragmatic politics of transformation. Journal of $R u$ ral Studies, 19(1), 77-86. https://doi.org/10.1016/ S0743-0167(02)00041-4

Hassanein, N. (2008). Locating food democracy: Theoretical and practical ingredients. Journal of Hunger \& Environmental Nutrition, 3(2/3), 286-308, https:// doi.org/10.1080/19320240802244215

Hasson, A. (2019). Building London's food democracy: Assessing the contributions of urban agriculture to local food decision-making. Politics and Governance, $7(4)$, 154-164.

Herring, R. J. (2015). How is food political? Market, state and knowledge. In R. J. Herring (Ed.), The Oxford handbook of food, politics, and society (pp. 3-40). New York, NY: Oxford University Press.

Holt-Gimenez, E., \& Shattuck, A. (2011). Food crises, food regimes and food movements: Rumblings of reform or tides of transformation? Journal of Peasant Studies, 38(1), 109-144. https://doi.org/10.1080/ 03066150.2010 .538578

Jhagroe, S. (2019). Food citizenship and governmentality: Neo-communitarian food governance in The Hague. Politics and Governance, 7(4), 190-201.

Lang, T. (1999). Food policy for the 21st century. In M. Koc, R. MacRae, L. J. A. Mougeot, \& J. Welsh (Eds.), For hunger-proof cities: Sustainable urban food systems (pp. 216-224). Ottawa: International Development Research Centre Books.

Lang, T. (2005). Food control or food democracy? Reengaging nutrition with society and the environment. Public Health Nutrition, 8(6A), 730-737. https://doi. org/10.1079/PHN2005772

Lang, T., \& Heasman, M. (2004). Food wars: The global battle for mouths, minds and markets. London: Earthscan.

Larson, N., Perry, C. L., Story, M., \& Neumark-Sztainer, D. (2006). Food preparation by young adults is associated with better diet quality. Journal of the American Dietetic Association, 106(12), 2001-2007. https:// doi.org/10.1016/j.jada.2006.09.008

Levkoe, C. Z. (2006). Learning democracy through food 
justice movements. Agriculture and Human Values, 23(1), 89-98, https://doi.org/10.1007/s10460-0055871-5

Lohest, F., Bauler, T., Sureau, S., Van Mol, J., \& Acten, W. M. J. (2019). Linking food democracy and sustainability on the ground: Learnings from the study of three alternative food networks in Brussels. Politics and Governance, 7(4), 21-31.

Lorenzini, J. (2019). Food activism and citizens' democratic engagements: What can we learn from marketbased political participation? Politics and Governance, 7(4), 131-141.

Micheletti, M., \& Boström, M. (2013). Political consumerism: Consumer choice, information, and labeling. In P. B. Thompson \& D. M. Kaplan (Eds.), Encyclopedia of food and agricultural ethics (1-8). Dordrecht: Springer. https://doi.org/10.1007/97894-007-6167-4_244-4

Micheletti, M., \& Stolle, D. (2012). Sustainable citizenship and the new politics of consumption. The $A N$ NALS of the American Academy of Political and Social Science, 644(1), 88-120. https://doi.org/10. $1177 / 0002716212454836$

Moore Lappé, F. (1971). Diet for a small planet. New York, NY: Ballantine Books.

Peters, Y., \& Tatham, M. (Eds.). (2016). Democratic transformations in Europe: Challenges and opportunities. New York, NY: Routledge. https://doi.org/10.4324/ 9781315657646

Pollan, M. (2008). In defense of food: An eater's manifesto. New York, NY: Penguin Press.

Prost, S. (2019). Food democracy for all? Developing a food hub in the context of socio-economic deprivation. Politics and Governance, 7(4), 142-153.

Renting, H., Schermer, M., \& Rossi, A. (2012). Building food democracy: Exploring civic food networks and newly emerging forms of food citizenship. International Journal of Sociology of Agriculture and Food,
19(3), 289-307.

Rosanvallon, P. (2011). Democratic legitimacy: Impartiality, reflexivity, proximity. Princeton, NY: Princeton University Press.

Shiva, V. (2014). Future of food: Dictatorship or democracy? Arizona State University. Retrieved from https://sustainability.asu.edu/media/wrigleylecture-series/vandana-shiva-future-of-food

Sieveking, A. (2019). Food policy councils as loci for practising food democracy? Insights from the case of Oldenburg, Germany. Politics and Governance, $7(4)$, 48-58.

Sørensen, E., \& Torfing, J. (2005). Network governance and post-liberal democracy. Administrative Theory \& Praxis, 27(2), 197-237. https://doi.org/10.1080/ 10841806.2005.11029489

Tilzey, M. (2019). Food democracy as 'radical' food sovereignty: Agrarian democracy and counterhegemonic resistance to the neo-imperial food regime. Politics and Governance, 7(4), 202-213.

van de Griend, J., Duncan, J., \& Wiskerke, J. S. C. (2019). How civil servants frame participation: Balancing municipal responsibility with citizen initiative in Ede's food policy. Politics and Governance, 7(4), 59-67.

Voß, J.-P., \& Guggenheim, M. (2019). Making taste public: Industrialized orders of sensing and the democratic potential of experimental eating. Politics and Governance, 7(4), 224-236.

Welsh, J., \& MacRae, R. (1998). Food citizenship and community food security: Lessons from Toronto, Canada. Canadian Journal of Development Studies/Revue Canadienne D'études du Développement, 19(4), 237-255. https://doi.org/10.1080/02255189. 1998.9669786

Wilkins, J. L. (2005). Eating right here: Moving from consumer to food citizen. Agriculture and Human Values, 22(3), 269-273. https://doi.org/10.1007/ s10460-005-6042-4

\section{About the Authors}

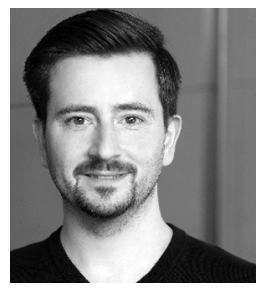

Basil Bornemann is a Post-Doctoral Researcher and Lecturer at the Sustainability Research Group, University of Basel. He has an interdisciplinary study background in environmental sciences and holds a doctoral degree in political science. His research focuses on sustainability-oriented governance transformations and their democratic implications in different fields of study, such as energy and food. He is further interested in principles and practices of transformative sustainability science.

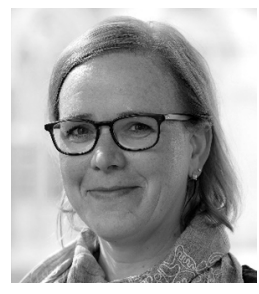

Sabine Weiland is Associate Professor of political science at Lille Catholic University, affiliated with the European School of Political and Social Sciences. She is the Director of the ESPOL-LAB Research Centre for European and International Politics, and the Head of the MA Food Politics programme. Her research interests are in food politics, environmental governance, reflexive governance, and sustainable development and transformation. 